\title{
First Time Seen
}

National Cancer Institute

\section{Source}

National Cancer Institute. First Time Seen. NCI Thesaurus. Code C159695.

An indication of the first time that a particular event or status was noted. 